\title{
KDO JE ALKIBIADÉS? \\ O různých identitách v dialogu Alkibiadés větší
}

\author{
Jakub Jirsa
}

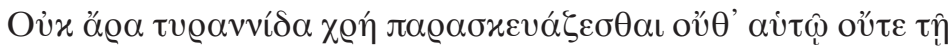

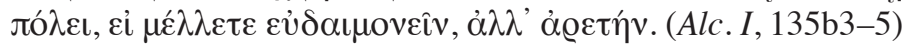

V předloženém článku bych rád obhájil tvrzení, že dialog Alkibiadés pracuje se dvěma různými pojetími ,jác“ a ve svém závěru naznačuje jejich vztah. ${ }^{1}$ Za účelem interpretace uvedeného dialogu rozlišuji odpověd', která popisuje naši praktickou identitu, a odpověd’ odkrývající naše hlubší, konstitutivní ,jáa.'2 Za pomoci těchto dvou různých pojetí ,jáa“ bude také interpretován vztah mezi různými částmi dialogu. V závěru textu se dostanu k výkladu vztahu mezi jednotlivými typy ,já““ 3

O různých typech či významech pojmu ,já“ hovoří jak antičtí, tak moderní interpreti. ${ }^{4}$ Jejich interpretace se však soustředí výhradně na

1 K diskusi o pravosti tohoto dialogu srv. N. D. Smith, Did Plato write the Alcibiades I?, in: Apeiron, 37, 2004, str. 97-99, a J. Jirsa, Authenticity of the Alcibiades I: Some Reflections, in: Listy filologické, 3-4, 132, 2009, str. 225-244. Jelikož nebudu mluvit o dialogu Alkibiadés menší, v následujícím článku označuji dialog Alkibiadés větší pouze názvem Alkibiadés.

2 Tyto názvy nejsou pokusem zavést určitou kategorizaci. Jsou to pracovní označení pro různé obsahy odpovědí na otázku „Kdo jsem?““.

3 Už někteří antičtí komentátoři, např́íklad Damaskios a Olympiodóros, tvrdí, že dialog nemá jen jeden skopos, ale že významů či hlavních témat tohoto dialogu je více. Viz Olympiodoros, In Plat. Alc. 9,22-23, srv. též F. Renaud - H. Tarrant, The Platonic Alcibiades I: The Dialogue and its Ancient Reception, Cambridge 2015, str. 230-231, a H. Tarrant, Olympiodorus and Proclus on the Climax of the Alcibiades, in: International Journal of the Platonic Tradition, 1, 1, 2007, str. 16. Podle Olympiodóra dialog prochází skrze různé úrovně ctnosti. Obecně lze říci, že antičtí komentátoři v dialogu vidí progresivní uspořádání. Srv. M. Griffin, Introduction, in: Olympiodorus, Life of Plato and On Plato First Alcibiades 1-9, London 2015, str. 9-10.

4 K interpretacím dialogu Alkibiadés v antice a ke komentářrum Prokla, Damaskia a Olympiodora srv.: A. P. Segons, Proclus: Sur le premier Alcibiade de Platon, I, Paris 1985, str. vii-civ; F. Renaud - H. Tarrant, The Platonic Alcibiades I: The Dialogue and its Ancient Reception, část II. Jako př́íklad moderních interpretací mohou 
druhou polovinu dialogu Alkibiadés, kde dochází k odlišení pojmů

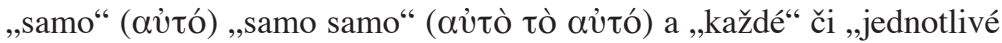
samo“ ( $\alpha$ ưò Ěr $\alpha \sigma \tau o v) .{ }^{5}$ Domnívám se, že tyto rozdíly jsou relevantní uvnitř kategorie konstitutivního ,já“, k němuž však v rámci dialogu vede cesta skrz diskusi naší praktické identity. V první části článku nejprve systematicky rozliším dvě možné odpovědi na otázku „Kdo jsem?“‘,které budou ilustrovány př́klady z antické literatury a odkazem na chápání tzv. praktické identity v díle Christine Korsgaardové. Vyjasnění těchto odpovědí pokládám za důležité, jelikož přispívají k porozumění argumentaci v dialogu Alkibiadés. ${ }^{6}$

Takto lze také vysvětlit jednotu dialogu, který se po úvodu (103a-106a) věnuje Alkibiadovým předpokladům pro politickou činnost v obci (106b-124a). V rámci této diskuse se také nachází protreptická pasáž, kde Sókratés Alkibiadovi vyloží důležitost péče o sebe sama (119a-124a). Následující interpretace ukáže, že tato první část dialogu se věnuje ,jä“ ve smyslu praktické identity. ${ }^{7} \mathrm{~V}$ druhé polovině dialogu se pak Sókratés věnuje péči o sebe sama a hledání odpovědi na otázku, co

sloužit J. Annas, Self-Knowledge in Early Plato, in: D. O’Meara (vyd.), Platonic Investigations, Washington 1985, str. 111-137; J. Brunschwig, La déconstruction du „connais-toi toi-même“ dans l'Alcibiade Majeur, in: Recherches sur la Philosophie et le Langage 18, 1996, str. 61-84; D. M. Johnson, God as the True Self: Plato's Alcibiades I., in: Ancient Philosophy, 19, 1999, str. 1-19; C. Gill, Self-Knowledge In Plato's Alcibiades, in: S. Stern-Gillet - K. Corrigan (vyd.), Reading Ancient Texts, I, Presocratics and Plato, Leiden 2006, str. 97-112; A. Joosse, Dialectic and Who We Are in the Alcibiades, in: Phronesis, 59, 1, 2014, str. 1-21; P. Remes, Reason to Care: The Object and Structure of Self-Knowledge in the Alcibiades I., in: Apeiron, 46, 3, 2013, str. 270-301. K dispozici je také český sborník A. Havlíček - J. Jinek (vyd.), Platónuv dialog Alkibiadés, Praha 2009.

5 Platón, Alc. I, 129a-b a 130d.

6 Další možný způsob tázání po lidské identitě v dialogu Alkibiadés nalézá K. Thein, Člověk, duše a sebepoznání, in: A. Havlíček - J. Jinek (vyd.), Platónův dialog Alkibiadés, Praha 2009, str. 49-51. Charakteristickým znakům lidství, které podle Theina Oidipús rozpoznává v hádance Sfingy, v dialogu odpovídají jednak letmo zmíněné momenty intencionality spojené s užíváním, jednak řeč (logos) jakožto předmět tohoto užívání (129b-e). K této pasáži viz R. Taylor, Persons and Bodies, in: American Philosophical Quarterly, 1, 16, 1979, str. 67-72; v češtině viz A. Havlíček, Duše, tělo a ,já‘, in: A. Havlíček - J. Jinek (vyd.), Platónův dialog Alkibiadés, str. 128-130.

7 Dělení dialogu není v textu jasně ohraničeno, většina interpretů však dělí dialog podobně jako já, a to v místě $124 \mathrm{a}-\mathrm{b}$, kde končí Sókratova řeč o perských a spartských vládcích a začíná diskuse o péči o sebe samého. Srv. K. Döring, Platon, Erster Alkibiades, Göttingen 2016, str. 65-66, nebo dělení kapitol in: F. Renaud H. Tarrant, The Platonic Alcibiades I: The Dialogue and its Ancient Reception. 
znamená ,já“ jakožto předmět péče o sebe sama (124b-129b), toto zkoumání se ještě prohlubuje výkladem o poznání sebe sama (129b-133c). Tato druhá polovina dialogu se věnuje ,já“ v konstitutivním slova smyslu. V závěru dialogu (133c-135e) se Sókratés vrací na úroveň praktické identity a ukazuje, v jakém smyslu je poznání tzv. konstitutivního já určující či zakládající pro náš dobrý život. ${ }^{8}$

\section{Jedna otázka a mnohé odpovědi}

Vlastním tématem článku jsou odlišné odpovědi na otázku „Kdo jsem?“ v dialogu Alkibiadés. Následující odkazy do antických a moderních textů slouží k objasnění či ilustraci těchto odpovědí a jejich rozdílnosti. Nejde tedy o komplexní výklad tématu identity obecně ani identity v antickém myšlení.

Jedna odpověd’ na otázku „Kdo jsem?“ vychází z naší praktické identity. Sebepoznání ve smyslu poznání praktické identity zahrnuje například fakt, že jsem otcem, že jsem přednášející a že tyto dva aspekty mého já je leckdy těžké skloubit dohromady. Praktická identita zahrnuje naše společenské role, náš původ, rodinné vztahy, vzdělání, zaměstnání či bohatství. Pojem ,praktická identita“ jsem si vypůjčil od zmíněné Christine Korsgaardové. Podle ní identity, resp. části naší identity, poskytují důvody pro naše jednání a zároveň s sebou přinášejí závazky (a případně i jejich konflikty). Porušit tyto závazky znamená „ztrátu integrity a také identity, nebýt již tím, kým člověk je“. 9 „Vztah

8 V této závěrečné pasáži text vyjasňuje hierarchii poznání jednotlivých,,já“, kterou zmiňuje např. A. Joosse, Dialectic and Who We Are in the Alcibiades, str. 11-12. Ke struktuře dialogu srv. F. Renaud - H. Tarrant, The Platonic Alcibiades I: The Dialogue and its Ancient Reception, str. 99-101, př́ipadně česky P. Hobza, , Já ' mezi péčí o sebe a poznáním duše, in: A. Havlíček - J. Jinek (vyd.), Platónův dialog Alkibiadés, str. 26-27.

9 C. M. Korsgaard, The Sources of Normativity, Cambridge 1996, kap. 3.3.1. Níže uvádím i odkazy na Platónovy dialogy, kde tento typ identity přichází ke slovu. Korsgaardové jde primárně o konstrukci závazků vycházejících z naší vlastní praktické identity. Základem možnosti této identity je schopnost reflexe, a tedy lidská racionalita a autonomie, což jsou tudíž nenahodilé základy etiky; viz C. M. Korsgaard, The Sources of Normativity, kap. 3.4.7. Podobnost př́ístupu v Platónově dialogu Alkibiadés a v textu C. M. Korsgaardové spočívá v rozpoznání normativního aspektu rolí či pozic v rámci praktické identity, jejž lze vyložit podmínečnou větou: „Chceš-li být politikem, měl bys ..." Předpokládáme-li, že jsem si danou roli vybral a jsem schopen ji reflektovat, pak přijetí této role jistým způsobem určuje moje jednání (viz Alc. I, 105c-e, 106c, 108e-109a, 109d, 119a-c, 124a-c, 134c). Rozdílnost 
k sobě samému mne zavazuje. Mohu sám sebe zavazovat, jelikož jsem si sám sebe vědom." ${ }^{10}$

Když si uvědomím, co to je být otcem či učitelem, objevuji tedy závazky, které jsou v těchto identitách založeny a které musím přijmout, mám-li být otcem či učitelem. Julia Annasová k tomu v článku o poznání sebe sama v dialogu Alkibiadés poznamenává: „Náležité chápání toho, kdo a co jsem, je vždy zároveň také chápáním mého poslání a s ním spojených povinností ohledně toho, co mohu a nemohu náležitě dělat." ${ }^{11}$ Pokud se takto podíváme na známý Oidipův případ, je jeho sňatek s Iokasté nepřípustný právě kvůli jeho rodinnému původu, o kterém Oidipús nic neví.

V mnoha dialozích vidíme, jak Platónův Sókratés během elenchu využívá rozpory či nesoulad mezi skutečností a mylným obrazem praktické identity, který si o sobě vytvořili jeho partneři v dialogu. ${ }^{12}$ Praktická identita totiž s sebou přináší jak povinnosti, tak očekávání. Pokud by např́íklad někdo o sobě tvrdil, že je odborníkem na Tarského pojetí pravdy, lze očekávat, že by o něm dokázal podat odpovídající výklad. Pokud by to dotyčný nedokázal, jeho odbornictví by bylo zpochybněno. V mnoha dialozích pak Sókratés otevírá dialektickou debatu zkoumáním toho, co by jeho partneři v dialogu měli znát, když se pokládají za odborníky v té či oné oblasti: generálové Lachés a Nikias hovoří o statečnosti, Euthydémos a Dionysodóros, kteří se sami považují za učitele ctnosti, hovoří o výchově k mravnosti (Euthyd.273d), sofisté Prótagoras a Hippias o dobru či krásnu (Prot. 317b-318a; Hipp. Ma. 282d-e; srv. Hipp. Mi. 363c-d, 364a) a Ión jakožto rapsód hovoří o všem, co lze nalézt v Homérových básních (Ion, 530c-d). V jednotlivých dialozích Sókratés následně testuje proklamovanou identitu těchto odborníků, čímž vlastně

jejich přístupu pak spočívá především v tom, že podle Platóna naše konstitutivní já vytyčuje normativní principy pro naše jednání v rolích praktické identity, zatímco Korsgaardové postačuje samotná reflexe těchto rolí. Jednoduše řečeno, abychom žili št'astný, resp. správný život, musíme podle Platóna poznat, co jsme ve smyslu našeho konstitutivního já, zatímco podle Korsgaardové není poznání naší racionality a autonomie, které jsou v základu možnosti volby a reflexe, ke správnému životu nutné.

10 C. M. Korsgaard, The Sources of Normativity, kap. 4.2.2.

11 J. Annas, Self-Knowledge in Early Plato, str. 121.

12 K epistemologickým aspektům elenchu spojeným s otázkou poznání sebe samého viz S. L. Rappe, Socrates and Self-Knowledge, in: Apeiron, 28, 1, 1995, str. 1-24. 
podrobuje zkoušce jejich osobní integritu. ${ }^{13}$ Vnitřní rozpor jejich identity je dán konfliktem mezi skutečností a jejich (většinou mylným) poznáním sebe sama:

„Ión: Já tvrdím, Sókrate [že rapsód může lépe než kdokoli jiný posoudit] všecky věci.

Sókratés: Ty netvrdíš, Ióne, že všecky; či jsi tak zapomnětlivý? Přece by neslušelo rapsódu, aby byl zapomnětlivý.

Ión: A co tedy zapomínám?

Sókratés: Nepamatuješ si, že jsi řekl, že rapsódské umění je různé od vozatajského?

Ión: Pamatuji.

Sókratés: Neuznával jsi tedy, že když je různé, bude také znát různé věci?

Ión: Ano.

Sókratés: Tedy podle tvé řeči nebude rapsódské umění ani rapsód znát všechno." ${ }^{14}$

Ión je přesvědčen o tom, že je výjimečný jakožto rapsód. To je na jedné straně pravdivé přesvědčení, pokud vyhrává soutěže a je jakožto rapsód oceňován. Na straně druhé zahrnuje jeho chápání sebe sama momenty, které jsou v jasném rozporu se skutečností: ačkoli tvrdí, že jakožto rapsód zná, resp. dokáže posoudit všechny věci, v jednotlivých případech není schopen podat relevantní výklad. Ukazuje se tedy nejen to, že Ión by měl přehodnotit své chápání rapsódského umění, ale také to, že praktická identita s sebou vždy nese jisté nároky a jistá očekávání, kterým je třeba dostát. Korsgaardová přitom ukazuje, jak jsou jednotlivé aspekty této „praktické identity“ normativní: předkládají nám relevantní důvody pro naše jednání. ${ }^{15}$ Spolu s důvody a závazky přichází také očekávání. Sókratovi partneři v dialogu ukazují, jak se mýlí ve svém poznání sebe samých, nenaplňují očekávání, která chtějí vzbuzovat, a nejsou schopni

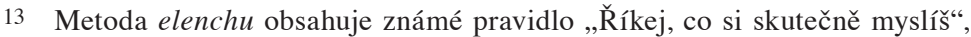
což posiluje osobní aspekt celého vyvracení (viz Gorg. 472b-c, 500c; Resp. 346a; Crito, 49c-d; Prot. 331c); srv. H. Tarrant, Socratic Method and Socratic Truth, in: S. Rappe - R. Kamtekar (vyd.), A Companion to Socrates, Oxford 2005, str. 254-72; stále důležitým článkem je G. Vlastos, The Socratic Elenchus, in: Oxford Studies in Ancient Philosophy 1, 1983, str. 27-58.

14 Platón, Ion, 539e-540a. Není-li uvedeno jinak, všechny citované překlady Platónových dialogů jsou od Františka Novotného.

15 C. M. Korsgaard, The Sources of Normativity, kap. 3.3.1. 
jednat v souladu s tím, jak se sami představují (například nedovedou posoudit všechny věci, nedovedou vychovávat k ctnosti apod.). Naopak Sókratés je zřetelně zpodobněn jako osoba, která velmi dbá na svoji vlastní integritu:

„A přece já se domnívám, můj milý, že by bylo lépe, aby má lyra byla rozladěna a falešně hrála a aby falešně zpíval sbor, který bych řídil, a aby celý svět se mnou nesouhlasil a mluvil opačné věci, nežli abych já sám jediný byl se sebou v nesouladu a sobě odporoval." ${ }^{16}$

Platónův Sókratés je tedy předobrazem ,zkoušeného“ či ,zkoumaného života“, tj. života, v němž dotyčný sám prověřuje a zkouší svoji integritu (Apol.38a). Sókratés se tak na rozdíl od svých partnerů v dialogu nedostává do výše uvedených rozporů.

Avšak i Sókratés v první části dialogu Faidros slavně popírá jistou variantu poznání sebe sama. Když s Faidrem probírá mytologické významy místa jejich konverzace, Faidros se jej v jednom okamžiku zeptá, zda těmto příběhům věří (Phaedr. 294c4). Sókratés odpovídá, že na tato zkoumání nemá čas, protože ještě nedovede podle nápisu v Delfách poznat sám sebe:

„... proto se mi zdá směšno, když ještě toto neznám, zkoumat cizí věci. Proto tedy nechávám tyto věci být a věře tomu, co se o nich obecně myslí, zkoumám, jak jsem právě řekl, nikoli je, nýbrž sám sebe, zdali jsem nějaké zvirre nad Tyfóna zavilejší a soptivější, či tvor krotší a jednodušší, od přírody účastný jakéhosi božského a nesoptivého údělu."17

Tato pasáž připouští širokou škálu interpretací ve vztahu k poznání sebe sama. Harvey Yunis přitom upozorňuje, že dichotomie, které se v této pasáži vyskytují, jsou Platónem užívány i v jiných dialozích, kde označují základní vlastnosti duše. ${ }^{18}$

\footnotetext{
16 Platón, Gorg. 482b-c.

17 Týž, Phaedr. 229e-230a.
}

18 H. Yunis, Plato: Phaedrus, Cambridge 2011, str. 94. Na jedné straně zde figuruje mýtické monstrum Tyfón, na straně druhé bytost, která má jistý podíl na božském. Tyfón je bytost reprezentující násilí, bezpráví, zlo a bezbožnost. Jeho popisy se liší u jednotlivých autorů a je složité získat koherentní obraz, což dobře odpovídá Tyfónově povaze: Tyfón prý má sto hlav, několik nohou a rukou, tři těla a podle některých i křídla. Tyfón je nepřítelem bohů a jednou z mála bytostí, která zřejmě bohy 
Sókratés později v dialogu rozebírá dvě zásadní vlastnosti lidské duše: její věčný pohyb a neredukovatelnou komplexitu. ${ }^{19}$ Duše je stále

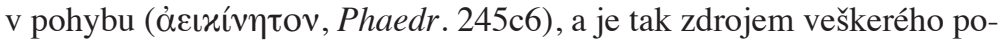
hybu a podobá se ,srostlině okř́ídleného spřežení a vozataje“ (246a6-7). Obraz lidské duše, resp. duše živých bytostí, které nejsou bohy, je pak složen ze dvou koní opačných přirozeností a charakterů, což činí řízení nesnadné. ${ }^{20}$ Tato komplexita je základem pro různost živých bytostí, kterou popisuje Adrasteiin zákon, zákon nutnosti (248c-249b). Pro můj výklad je důležité, že obraz lidské duše v Palinodii stejně tak jako mytologická pasáž 229e-230a zdůrazňuje komplexitu nás samých a mnohost podob, kterých je lidská duše schopná. ${ }^{21}$

Když tedy v souladu s dialogem Faidros a - jak uvidíme - i s dialogem Alkibiadés má odpověd’ na otázku „Kdo jsem?“” zní, že jsem duše, odpovídám druhým možným zpo̊sobem. ${ }^{22}$ Tomuto způsobu lze říkat konstitutivní a odpověd’ ukazuje na naše konstitutivní ,jác. V rámci dialogů tato odpověd ponechává prostor pro flexibilitu a rozmanitost v rámci lidské přirozenosti, jelikož se ukazuje, že duše může nabývat různých

může vážně ohrozit. Viz Aischylos, Prom. 356; Euripidés, Heracl. 1272; Hésiodos, Theog. 305-7; Apollodóros, Bibl. I,6,3 a II,5,10-11. Tyfóna charakterizuje nepř́ítomnost pevné podoby či řádu, na kterých by bylo možné založit jakkoli jednoduché poznání sebe sama, srv. výklad v C. Griswold, Self-Knowledge in Plato's Phaedrus, Pennsylvania 1986, str. 40. Druhý krajní bod je charakterizován pomocí „,božského údělu“ a spolu s tímto údělem přichází i jednoduchost a řád.

19 Viz detailní rozbor in: K. Thein, Člověk, duše a sebepoznání, str. 53.

20 Podle Platóna spočívá rozdíl mezi dušemi bohů a duší ostatních živých bytostí ve dvojím: role vozataje (Phaedr. 246b1-2) a koně opačných povah (246b2-3), jejichž řízení je tudíž složité a problematické.

21 Tyto dvě pasáže z dialogu Faidros ve své interpretaci spojuje i C. Moore, Socrates and Self-Knowledge, Cambridge 2015, str. 176-177. Mytologická pasáž nehovoří explicitně o duši. Viz však pozn. 18; Platón volí pojmy, které mu na jiných místech slouží k charakterizaci duše. Tématem mytologické pasáže je poznání sebe sama, kterého se nám jistým způsobem dostává ve výkladu o duši v Palinodii, kde Platón několikrát hovoří o „nás“ (Phaedr. 246b1-4). Pokud Sókratés v mytologické pasáži tvrdí, že nedokáže ještě poznat sám sebe, a v Palinodii pod pojmem „my“ chápe naši duši, je legitimní se domnívat, že i v mytologické pasáži se hovoří o duši. S tímto momentem Sókratovy neznalosti souvisí také jeho tvrzení, že bude hovořit

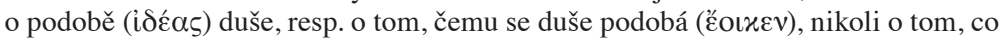

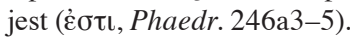

22 Srv. Phaedr. 246b1-4 a 255c1-d6; k identifikaci duše a ,já“ v dialogu Faidros srv. C. Moore, Socrates and Self-Knowledge, str. 138-139, 176-177; nebo C. Griswold, Self-Knowledge and the Idea of the Soul in Plato's Phaedrus, in: Revue de métaphysique et de morale, 4, 86, 1981, str. 490. 
podob a charakteristik. Pojem „konstitutivní“ zde chápu ve smyslu „,zakládající“. Dialog Alkibiadés pak podle mne ukazuje, v jakém ohledu „já“ chápané jako duše poskytuje normativní základy pro jednání v rámci našich praktických identit. ${ }^{23}$

V této části jsem tedy rozlišil dvě možné odpovědi na otázku „Kdo jsem?"“, které nejsou navzájem převoditelné. Tyto odpovědi mají zaprvé význam ,praktické identity“ či ,praktických identit“, ${ }^{24}$ které jsou spojeny s mou integritou; tento význam je užíván například během elenchu v platónských dialozích. Za druhé, daná odpověd’ může odhalit mé konstitutivní ,jáa“, např́íklad moji duši.

V následující části svého článku bych rád ukázal, že dialog Alkibiadés probírá podrobně oba z těchto významů: praktickou identitu v první části dialogu a konstitutivní ,jä“ v jeho druhé části. V závěrečné části článku pak navrhnu interpretaci vztahu těchto dvou významů, jak se objevuje v dialogu Alkibiadés.

\section{Praktická identita v dialogu Alkibiadés}

Dialog Alkibiadés otevírá oslovení ó pai Kleiniú, synu Kleiniův, což rozhodně není časté oslovení partnera v dialozích. ${ }^{25}$ Nick Denyer připomíná, že toto oslovení slouží jako připomínka původu dané osoby, včetně závazků, které jsou v původu a rodinné příslušnosti obsaženy. ${ }^{26}$ Dialog tak rovnou začíná jedním z aspektů praktické identity, o které bych nyní rád hovořil.

Samotné téma poznání sebe, resp. přinejmenším určitého kognitivního vztahu k sobě samému, se v dialogu objevuje také velmi záhy. Jen po několika málo řádcích se Sókratés dostává k Alkibiadovým přesvědčením o sobě samém: Alkibiadés věř́, že vrozené vlastnosti jeho duše

23 Viz níže oddíl 4: Praktická identita a konstitutivní ,ja““.

24 Jednotlivec je podle Korsgaardové nositelem více ,identit“ či rolí (otec, učitel, kamarád apod.), souhrnně pak lze o tomto aspektu naší osoby hovořit jako o ,praktické identitě“, která je ve výše uvedeném smyslu komplexní.

25 Celkem jsem v dialozích nalezl osmnáct úplných patronymických oslovení (Crat. 384a8, 406b8; Philb. 19b5; Symp. 198a5; Alc. I, 103a1; Theag. 128c6; Charm. 169b5; Lys. 204b6, 207b8, 209a5; Euthyd. 278e2, 279d2; Prot. 328d8, 335d7-8; Meno, 76e6; Hipp. Mi. 373a6; Resp. 427d1; Lach. 180d7). Pouze v dialozích Kratylos a Alkibiadés jde o první oslovení partnera v dialogu. Srv. F. Renaud - H. Tarrant, The Platonic Alcibiades I: The Dialogue and its Ancient Reception, str. 27.

26 N. Denyer, Plato, Alcibiades, Cambridge 2001, str. 83. 
a těla jsou natolik vynikající, že je zcela soběstačný a nikoho jiného nepotřebuje (104a). ${ }^{27}$ Většina komentátorů souhlasí, že od této pasáže až do místa 124a-b má text dialogu především protreptický cíl: odhalit Alkibiadovu nevědomost a nedostatečnost, přivést jej k uznání těchto nedostatků, a tedy jej i přesvědčit, že je třeba pečovat o sebe sama. ${ }^{28}$

Tato obecně protreptická pasáž je rozdělena do tří částí, v nichž se opakovaně pojednává o stejných tématech, pokaždé však situovaných do jiného kontextu s jiným referenčním bodem. Všechny tři pasáže pojednávají o Alkibiadových vrozených talentech ${ }^{29}$ rodinném původu, vzdělání či odbornosti, a nakonec i jeho majetku. ${ }^{30} \mathrm{~V}$ prvním kontextu je referenčním bodem sám Alkibiadés: jeho představy o něm samém jsou srovnávány s tím, jak se to s ním ve skutečnosti má. Cílem je ukázat závěry, které plynou z Alkibiadových představ a přesvědčení o vlastních vrozených talentech, původu, vzdělání a bohatství (104a2-106a2). V druhém kontextu jsou referenčním bodem athénští politici, které chce Alkibiadés překonat (106b11-119a7). Ve třetím kontextu je pak Alkibiadés srovnáván s králi Sparty a Persie (119a8-124a8), s nimiž by Alkibiadés měl soupeřit, má-li skutečně takové představy o sobě samém a s nimi spojené touhy odhalené Sókratem v první části jejich diskuse.

Alkibiadovy touhy a záměry jsou založeny na představách, které má

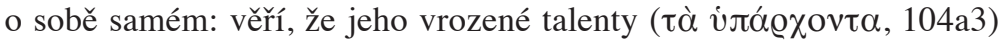
jsou tak veliké, že nikoho a nic nepotřebuje. Je krásný a vysoký, tj. dobře vypadá (104a5). Dále má vysoké mínění o svém původu i obci, z níž pochází (104a7). Navíc se domnívá, že jeho moc je o to větší, že jeho vychovatelem byl Periklés (104b4-6), a konečně také proto, že je bohatý $(104 c 1)$.

27 Souhlasím s Pauliinou Remesovou, že tato přesvědčení mohl zastávat i historický Alkibiadés, viz P. Remes, Reason to Care, str. 271.

28 Srv. F. Renaud - H. Tarrant, The Platonic Alcibiades I: The Dialogue and its Ancient Reception, str. 79-80; ohledně antického dělení textu dialogu viz M. Griffin, Introduction, str. $36 \mathrm{nn}$.

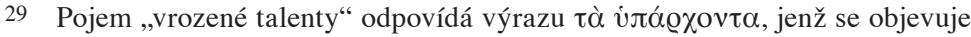
na místě 104a2-3; český překlad je inspirován pojmem „,natural assets“ vypůjčeným od Johna Rawlse. Rawlsova myšlenka spočívá v tom, že spravedlnost nesmí být založena na distribuci vrozených talentů, avšak pravidla, na jejichž základě společnost zachází s distribucí vrozených talentů, jsou součástí spravedlnosti.

30 Srv. Proklos, In Plat. Alc. 135,13-17. Proklos vyjmenovává moc, velikost, vládu, slast a bohatství jako cíle, které duše vyhledává v našem světě pro svoji zapomnětlivost a nevědomost. 
Když Sókratés o něco později zpovídá Alkibiada ohledně jeho nadějí a tužeb uspět v athénské politice, výslovně znovu otevírá téma jeho vzdělání, které, jak se zdá, sestává pouze ze čtení, psaní, hraní na kitharu a zápasení (106e4-9). Dále Sókratés argumentuje, že vrozené talenty, jako je krása, výška či původ, nejsou Alkibiadovi k ničemu, když přijde na to, aby radil Athéňanům (107b6-7). Stejně tak mu nepomůže ani bohatství (107b8-10). I když Alkibiadés v závěru této části rozhovoru konečně nahlédne svoji nevědomost (118b7), stále ještě by chtěl uniknout dalšímu nutnému kroku, jímž je péče o sebe sama:

„Alk.: Rad’me se společně, Sókrate. Po tvé řeči si to uvědomuji a uznávám to; ano, zdá se mi, že politikové jsou kromě několika málo nevzdělaní.

Sókr.: Nuže, co to znamená?

Alk.: Kdyby byli vzdělaní, musel by asi ten, kdo by se pokoušel s nimi zápasit, jít proti nim jako proti zápasníkům vyučen a vycvičen; takto však, když se i ti dali do politické činnosti bez odborné př́ípravy, nač by se člověk cvičil a trápil učením? Nebot' pokud jde

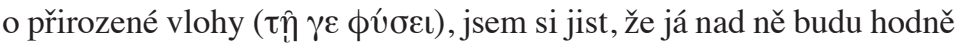
vysoko vynikat.“"31

Alkibiadés se však musí na základě vlastních tužeb a představ o sobě samém srovnávat nejen s místními politiky, ale také s vládci Sparty či Persie (120a). Tito vládci mají skvostný původ a dostalo se jim i vynikající výchovy. Proto se zdá, že jsou naprosto či úplně ctnostní ( $\tau \varepsilon \lambda \varepsilon \dot{o v} \varsigma$

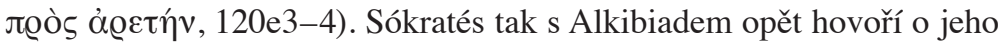
rodině, jejíž původ je však nesrovnatelně nižší v porovnání s genos těchto králů (120e6-121e1). Dialog se pak opět dostane k jeho vzdělání a odbornosti, které jsou ve srovnání s perskými princi skutečně mizivé (104b5-6), a konečně se hovoří o Alkibiadově bohatství, které nemůže být srovnáváno ani s bohatstvím králům, ani s majetkem jejich žen $(122 b 9-123 c 4) .^{32}$

31 Platón, Alc. I, 119b1-c1.

32 Tato pasáž věnující se spartským a perským královnám může být poukazem k Alkibiadově zženštilosti, na niž nacházíme odkazy v antické literatuře (viz pečlivý rozbor v: D. Gribble, Alcibiades and Athens: A Study in Literary Presentation, Oxford 1999, str. 71-73). Může však také sloužit k vystupňování Alkibiadova studu, který by jej měl vést k náležité péči o sebe samého. 
Jednotlivé pasáže tedy probírají Alkibiadovu postavu, původ, vzdělání a bohatství. ${ }^{33}$ Stojí za pozornost, že když Platón ve svých dialozích určuje něčí totožnost, používá k tomu právě tyto znaky. Pokud chceme vědět, kdo daný neznámý je, odpovědi se nám může dostat právě skrze popis jeho postavy, původu, vzdělání a bohatství. Prvním prŕíkladem může být představení mladého Theaitéta ve stejnojmenném dialogu, druhým příkladem jsou sofističtí bratři z ostrova Chios, Euthydémos a Dionysodóros, v dialogu Euthydémos.

V dialogu Theaitétos chce Theodóros prredstavit Sókratovi svého nadaného studenta. Toto představení stojí za pozornost také proto, že o Theaitétově identitě se dozvídáme prostřednictvím informací, které poskytuje jak Theodóros, tak Sókratés. Theodóros hovoří o Theaitétově vzhledu (Tht. 143e7-144a1), vrozených talentech (144a1-b6), přičemž od počátku jejich diskuse je zřejmé, že Theaitétos je odborníkem v matematice (144b2-3). Sókratés se dokonce ptá dříve na jeho původ než na jeho jméno (144b7). Theodóros si nepamatuje jméno otce, ale jelikož Theaitétos zrovna přichází, může jej Sókratovi ukázat a ten doplní informaci o jeho původu, $\mathrm{k}$ čemuž dodá i zmínku o jeho majetku (144c5-8). Sókratés však nezná mladíkovo jméno, což je skutečně ta poslední věc, na niž se zeptá.

Bratři Euthydémos a Dionysodóros jsou představeni na menším prostoru, ale výčet prvků důležitých pro vymezení jejich identity je stejný. Kritón otevírá dialog otázkou „Kdo to byl?“, kterou hned dvakrát opakuje (271a1, a5). Toto opakování odpovídá tomu, že to byly dvě osoby, které minulý večer rozmlouvaly se Sókratem. Jejich identita je pak odkryta pomocí prvků, které se objevují jak v Alkibiadovi, tak při představování Theaitéta: vzhled (272b1-3), genos (272c2), vzdělání, odbornost a bohatství (278c5 n.).

Totožnost Theaitéta, Euthydéma a Dionysodóra je tak pokaždé odkryta uvedením těch znaků, o nichž s Alkibiadem hovoří Sókratés v první

33 Každá z těchto pasáží také končí Alkibiadovou reflexí, díky níž se diskuse dostává na další úroveň. Nejprve Alkibiadés tvrdí, že Sókratés se zdá být ještě více atopos, než když spolu začali hovořit, zajímá se však, zda by Sókrata nemohl využít ke splnění svých tužeb a záměrů. Na konci druhé pasáže, jejímž cílem bylo srovnání Alkibiada s místními politiky, Alkibiadés souhlasí, že si již sám sebou není tak jistý, jelikož zjistil, že zastává protichůdné názory (117a-b). Zdá se, že již zde si Alkibiadés uvědomuje svá omezení, avšak nechce je přiznat a schovává se za nevzdělanost a nevědomost ostatních politiků (viz 119b-c, citováno výše). Konečně Alkibiadova reflexe výsledků dosavadní debaty umožní Sókratovi, aby přešel k péči o sebe, jelikož se zde Alkibiadés konečně vzdává: „Jakou to péči, Sókrate, je třeba vynakládati? Můžeš mi to vyložit? Vždyt' se nade všechno podobá, že jsi řekl pravdu“ (124b7-9). 
části dialogu. Domnívám se tedy, že jedním z témat v první části dialogu je Alkibiadova identita - vzhled, rodinný původ, vzdělání, odbornost a majetek, to všechno jsou prvky odpovědi na otázku „Kdo je to?“. Přesněji řečeno, první polovina dialogu Alkibiadés prochází prvky Alkibiadovy praktické identity a zkoumá integritu jeho představ o sobě samém. Na Alkibiadově představě o vlastní praktické identitě jsou pak postaveny jeho skutečné ambice, naděje a tužby. Sókratés však natřikrát ukazuje, že tyto ambice a očekávání neodpovídají realitě - Alkibiadovy představy o sobě samém jsou mylné a nezakládají se na skutečném poznání sebe samého, $\mathrm{k}$ němuž se jej Sókratés pokusí přivést $\mathrm{v}$ druhé části dialogu.

Na prríkladech z dialogu Theaitétos a Euthydémos jsem ukázal, že praktická identita je odpovědí na otázku „Kdo to je?“ i v jiných dialozích. V obou textech jsou dané osoby popsány pomocí svého vzhledu, původu, vzdělání i majetku. Důležité je, že praktickou identitu zde stále chápu jako komplexní odpověd’ na otázku „Kdo jsem?": různé role či dosažené pozice, které mohou smysluplně figurovat v odpovědi na tuto otázku, jsou bezprostředním obsahem praktické identity. ${ }^{34} \mathrm{Z}$ nich pak vychází naše ambice, závazky a případné očekávání druhých. Na otázku „Kdo jsi?““ bych neodpovídal např́klad výčtem toho, co znám či neznám, ${ }^{35}$ ani bych neodpovídal vyjmenováním svých ambicí a případných očekávání tazatele (tedy pokud bych jej nechtěl na základě těchto indicií přimět hádat). ${ }^{36}$

Teze, že první část dialogu Alkibiadés se zabývá praktickou identitou, je podpořena dvěma pasážemi, které se explicitně zabývají důsledky Alkibiadova chybného poznání sebe sama. Sókratés ukazuje, jaké důsledky a závazky plynou z rolí, do nichž se Alkibiadés pasuje. Vezmeme-li pak

34 Srv. C. Korsgaard, The Sources of Normativity, str. 101: „Your reasons express your identity, your nature; your obligations spring from what that identity forbids."

35 Zde je potřeba zmínit dialog Charmidés, v němž Sókratés představuje znalost sebe sama jako znalost toho, co člověk ví a co neví (Charm. 167a5-6), resp. jako ,jednu znalost, která nemá za předmět nic jiného, než samu sebe i ostatní znalosti a zároveň také neznalost“ (Charm. 167b11-c2). V tomto dialogu se však jedná o případné vymezení ,já“, které by odpovídalo mému pojmu konstitutivního já. Srv. F. Karfík, Poznání a sebevztah, in: A. Havlíček - J. Jinek (vyd.), Platónův dialog Charmidés, Praha 2007, str. 134-139; J. Jirsa, Sókratův „velký muž“, in: tamt., str. 151-161.

36 Je zřejmé, že praktická identita obsahuje jak role a postavení, které jsou výsledkem naší volby (např. povolání politika či role manžela), tak ty, které jsou nám dány (např. původ). U daných identit je důležitá i naše reflexe této danosti, přijetí či odmítnutí této identity (nakolik to je možné: nemohu odmítnout např. biologický fakt synovství, ale mohu různým způsobem odmítat veškeré morální či společenské závazky plynoucí z této skutečnosti). Reflexe je tak důležitým momentem při konstituci závazků plynoucích z naší praktické identity. 
vážně to, co si Alkibiadés myslí o svých schopnostech, vyplývá z toho, že by raději zemřel, než aby mu nebylo dovoleno rozšiřovat svoji moc a vládu (105a4-6). Pokud by mu nějaký bůh zakázal vládnout jinde než v Evropě, a Alkibiadova moc by se tak nemohla rozšriritit i do Asie, opět by raději zemřel, než aby žil takto omezen (105b7-c5). Celá pasáž jasně poukazuje na praktické důsledky, které vycházejí z Alkibiadova mylného přesvědčení o sobě samém. ${ }^{37}$

Další důsledky Alkibiadových chybných představ o sobě samém vycházejí najevo v pasáži 108e-109a. Podobně jako ve výše citovaném př́íkladu z Ióna i zde Sókratés využívá Alkibiadovy vlastní touhy a záměry, aby ukázal trhliny v jeho integritě:

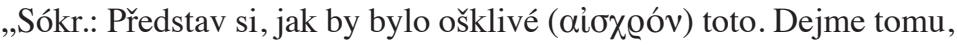
že bys mluvil a dával rady o stravování, že je lepší toto a nyní a v tomto množství, a tu by se tě někdo otázal: „Čemu říkáš lepší, Alkibiade? A ty bys o těchto dovedl říci, že lepším myslíš zdravější, ačkoli si neosobuješ, že jsi lékařem. Ale když jde o věc, o které si osobuješ, že jsi v ní znalcem, a o které budeš na schůzích dávat rady jakožto zna-

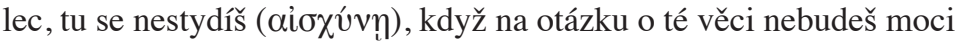

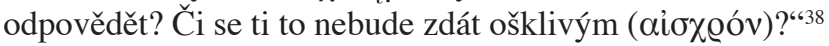

„Stud,“ píše Bernard Williams, „poukazuje na to, kdo jsem.“39 Sókratova argumentace zde vychází z Alkibiadových představ, v nichž se vidí jako zrozený k vládě nad druhými, avšak zároveň jako ten, kdo nepotřebuje žádné vzdělání a výchovu. Sókratés ukazuje ošklivé či zahanbující důsledky těchto přesvědčení a používá stud jako spouštěč Alkibiadovy ochoty poučit se z této nezáviděníhodné situace. Právě ostudné důsledky Alkibiadova pojetí sebe sama jej konečně přivedou až k porozumění, že by měl

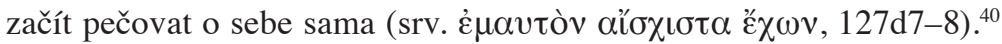

37 K normativnímu jazyku užitému v této pasáži srv. F. Renaud - H. Tarrant, The Platonic Alcibiades I: The Dialogue and its Ancient Reception, str. 44.

38 Platón, Alc. I, 108e6-109a4.

39 B. Williams, Shame and Necessity, Berkeley 1993, str. 93. Dialog otevírá

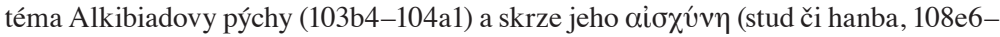

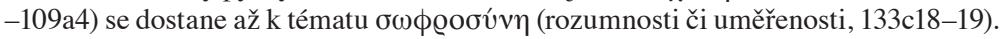
To je stav, který je podle Denyera tradičně spojován s aỉós (stud či ostych), srv. N. Denyer, Plato, Alcibiades, str. 238.

40 Viz Proklos, In Plat. Alc. 210,1-211,15; Proklos tvrdí, že Sókratés užívá studu v kombinaci s Alkibiadovou pýchou, aby Alkibiadés postoupil dále v porozumění sobě samému. 
Péče o sebe sama a pravý předmět této péče jsou předmětem druhé části dialogu. Sókratés tak od prvků praktické identity přechází k diskusi o tom, co jsem já sám, co mne konstituuje: je to moje tělo, moje duše, kombinace obou, či dokonce něco dalšího, co je ukryto ještě hlouběji?

\section{Konstitutivní ,jä“ v dialogu Alkibiadés}

Jelikož druhá část dialogu Alkibiadés je dnes velmi probírané téma,můj vlastní prrínos k výkladu zde bude poměrně malý. Ukáži, jak Sókratés představuje duši jakožto odpověd’ na otázku „Kdo jsem?“ ve smyslu konstitutivního ,já“, aby následně tuto odpověd’ označil za nepřesnou, leč postačující a naznačil zkoumání hlubšího či základnějšího významu ,jáa“ ${ }^{41}$ V následujícím oddíle shrnu základní argument a mé komentáře se budou týkat jen těch témat, která se bezprostředně vztahují k mé hlavní tezi o různých pojetích , jáa $\mathrm{v}$ dialogu Alkibiadés. ${ }^{42}$

Nejprve tedy oba účastníci dialogu souhlasili s tím, že Alkibiadés by měl „o sebe pečovat“ (119a8-9), přičemž Alkibiadés se dokonce dále dotazuje na způsob, jak by taková péče měla probíhat (124b7). Sókratés však přichází s novou otázkou: co to vlastně znamená pečovat o sebe sama (127e8)? Následuje argumentace, v jejîž první části Sókratés rozlišuje na jedné straně umění, které pečuje o to, co náleží k danému x, na straně druhé pak umění, které pečuje o samotné x (128d3-4). Než se dostaneme k samotnému umění, je však třeba najít to, o co bychom měli pečovat.

Odpověd’ na otázku po předmětu naší péče začíná notoricky problematickou pasáží 128e10-129a4. Obtíž je v samotné úvodní otázce: „A co, zdalipak bychom poznali, které umění činí lepším člověka samé-

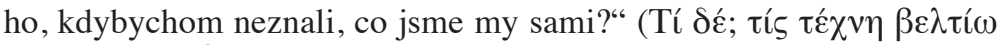

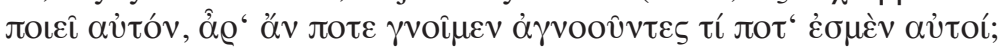
$128 \mathrm{e} 10-11)$.

Termín aủióv je uveden ve všech manuskriptech, ale překladatelé a komentátoři si s ním nevědí přesvědčivě rady. Novotný, podobně jako

41 Srv. A. A. Long, Platonic Souls as Persons, in: R. Salles (vyd.), Metaphysics, Soul and Ethics in Ancient Thought: Themes From the Work of Richard Sorabji, Oxford 2005, str. 173-191.

$42 \mathrm{Z}$ nedávných studií se druhé části dialogu týkají především A. Joosse, Dialectic and Who We Are in the Alcibiades; C. Moore, Socrates and Self-Knowledge, kap. 3.; P. Remes, Reason to Care; D. Werner, The Self-Seeing Soul in the Alcibiades I., in: Ancient Philosophy, 33, 2, 2013, str. 1-25. 
v angličtině Lamb, doplňuje „člověka“, aby bylo jasné, o čí „samo“ se zde jedná. ${ }^{43}$ Nick Denyer dokonce navrhuje změnu textu a namísto $\alpha u ̛ \tau o ́ v$ čte ơv $\theta \varrho \omega \pi$ ov. ${ }^{44}$ Recký text podle mne znamená, že nevíme, jaké umění činí jednoho lepším, aniž bychom věděli, co vlastně jsme. Nepřirozený pojem ,jednoho“ zde hraje roli anglického „one“ (srv. „,what art makes one better"), což odpovídá smyslu řeckého $\alpha u ̉ \tau o ́ ~ \varsigma .{ }^{45}$ Nejprve tedy musíme zjistit, o jakou entitu se jedná, a až následně najít odpovídající způsob péče.

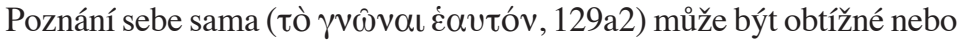
snadné, nicméně takové poznání je v každém případě potřeba, abychom věděli, jak o sebe pečovat ( Celá pasáž končí známou větou:

„Sókr.: Nuže tedy, jakým způsobem by se nalezlo samo to, čemu rríkáme ,sám"? Takto bychom totiž snad nalezli, co asi jsme my sami, avšak když jsme toho ještě neznalí, je to bezpochyby nemožné.“

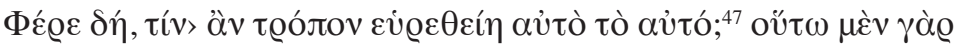

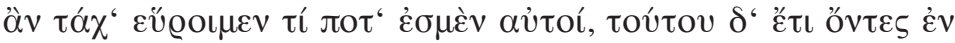

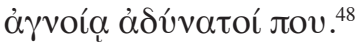

43 Hutchinson zde překládá v plurálu „us“; Jowett má jednoduše ,a man“; Pradeau-Marboeuf a Crosiset ve francouzštině uvádí „soi-même“; Schleiermacher překládá „einen selbst“ a nový německý překlad Klause Döringa uvádí sousloví „einen jeden selbst“. Překlad pomocí plurálu má oporu pouze v pozdější poznámce či citaci, viz N. Denyer, Plato, Alcibiades, ad loc. Doplňování pojmu ,„člověk“ nemá oporu v textu (proto Denyer přistupuje k emendaci textu, viz pozn. 44) a u sousloví ,einen jeden selbst“ je smysl podobně nejasný jako u řeckého originálu.

44 Viz N. Denyer, Plato, Alcibiades, str. 210-211; většina interpretů je k jeho emendaci zdrženlivá. Srv. interpretace in: C. Moore, Socrates and Self-Knowledge, str. 111 a A. Joosse, Dialectic and Who We Are in the Alcibiades, str. 17.

45 aủiós je zde užito $\mathrm{v}$ obecném slova smyslu, pojem neodkazuje k aủiò

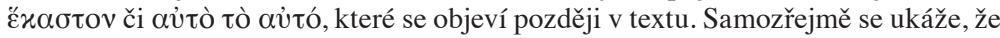

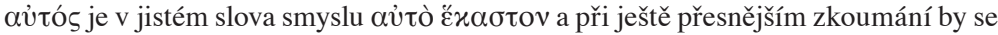

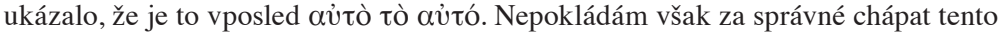
pojem na tomto místě za pomoci distinkce, která je provedena až později v dialogu.

46 aủió v místě 129a8 znamená „sebe“ ve významu entity, kterou musíme poznat, abychom věděli, jak o sebe sama pečovat.

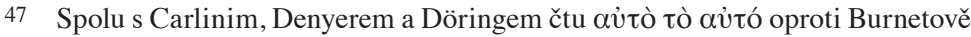

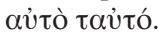

48 Platón, Alc. I, 129b1-2. 
K poznání, jak pečovat o sebe samé, tedy potřebujeme znát sami

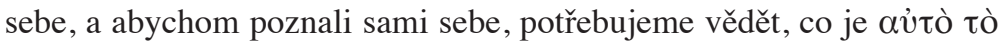

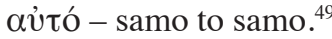

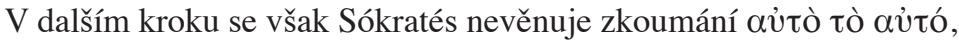
ale začíná s jednotlivými případy ,jä“. Alkibiadés v jednom okamžiku odpovídá „správně mluvíš (129b4) a Sókratés se chytí zmíněného „mluvení“, přičemž rozpracuje argumentaci, že on je tím, kdo užívá řeči. Pokud tedy naleznou, kdo je tento uživatel řečí, mohou nalézti, kdo či co je toto ,já“. Základním předpokladem zkoumání je, že uživatel se liší od užívané věci. Je zřejmé, že řemeslník se liší od nástroje, který užívá. Sókratés dále vyvozuje, že analogicky se řemeslník liší nejen od nástroje, ale i od svých rukou či očí, tj. od orgánů, které užívá ve své práci. ${ }^{50} \mathrm{Na}$ základě této úvahy pak Sókratés postoupí o krok dál: zdá se, že člověk užívá své tělo (129e3). Jelikož to, co užívá těla, je nazýváno duše

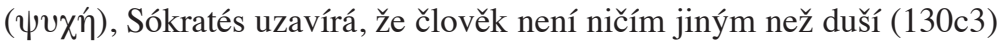
a duše je člověk (130c6). ${ }^{51}$

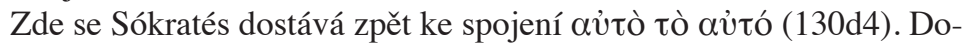
savadní zkoumání podle něj nebylo přesné, ale pouze dostatečné, jelikož

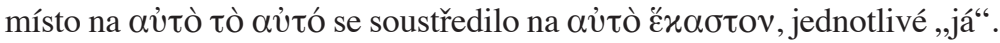
Toto jednotlivé já se nevztahuje k praktické identitě Alkibiada, která byla předmětem první části dialogu. Praktická identita byla jako téma opuštěna a předmětem zkoumání se stalo poznání nás samých (128e11). Před-

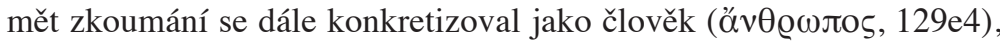
přičemž se ukázalo, že člověk je duše. To znamená, že znalost aủiò

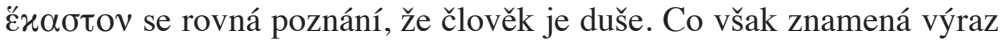

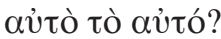

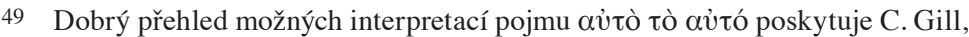
Self-Knowledge in Plato's Alcibiades, str. 98-99; Gill tvrdí, že řečtina nezná slovo odpovídající našemu pojmu ,já“ ve smyslu anglického „,self“. Oproti tomu A. Joosse, Dialectic and Who We Are in the Alcibiades, str. 11-12, předkládá interpretaci, která

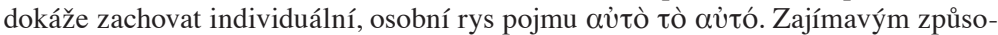
bem problematizuje snahy postulovat určitou entitu jako naše ,,já“ A. Montefiore, Self-Reality, Self-Respect, and Respect for Others, in: Midwest Studies In Philosophy, 3, 1978, str. 195-208.

50 Plútarchos uvádí, že v ohledu užívající - užívané byl Alkibiadés schopen jistého vztahu k sobě samému: uměl úmyslně využívat schopnost lidské přirozenosti měnit chování a přizpůsobovat se. Plútarchos jej zmiňuje jako příklad jedince, který užíval svůj charakter k působení na druhé, jako kdyby to byl nástroj. Viz Plútarchos, Vitae X orat. 23,3-5, srv. K. Thein, Člověk, duše a sebepoznání, str. 54-55.

51 Anthony Long hovoří o identifikaci duše s ,esencí lidské bytosti“, srv. A. A. Long, Platonic Souls as Persons, str. 175. 
Za prvé není jasné, zda se text dialogu Alkibiadés k výkladu o aủiò

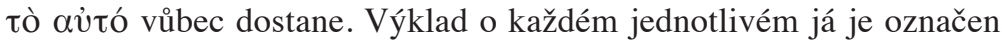

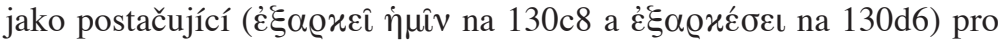
současný výklad o předmětu poznání sebe samého: „Kdo nám přikazuje poznati sebe sama, poroučí nám nabýti poznání o duši“ (130e7-8). Identifikace člověka a duše tedy není hlavním tématem dialogu, které by bylo následně jen převedeno na epistemologickou úroveň za pomoci analogie mezi poznáním sebe sama a zraku. ${ }^{52}$ Identifikace člověka a duše je pouze předběžným výsledkem, který se dále konkretizuje hledáním

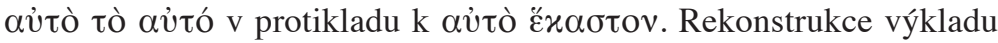

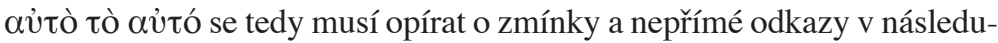
jícím rozboru péče o sebe samé (132b4-5) jakožto poznání nás samých $(132 \mathrm{c} 1-2,132 \mathrm{c} 7) .^{53}$

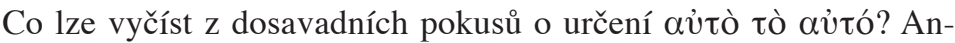

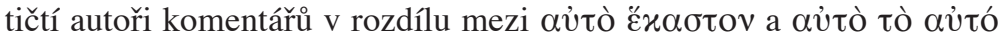
viděli posun mezi úrovněmi duše. ${ }^{54}$ Výrazně v protikladu k antickým

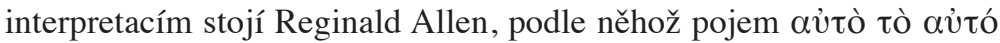

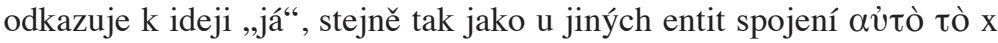
znamená ideu daného x. ${ }^{55}$ Tato interpretace se však opírá pouze o slovní

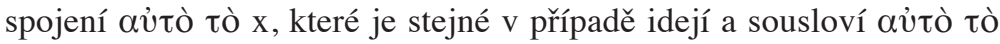

52 Podobně J. Brunschwig, La déconstruction du „connais-toi toi-même“ dans l'Alcibiade Majeur, str. 70-71, 76-77. Brunschwig hovoří o vývoji poznání sebe sama od duše, která je podle něj „osobním“ já, k neosobnímu já, jímž je bohu podobný rozum.

53 Pro argumentaci, podle níž poznání nás samých je zároveň péčí o nás samé, viz J. Jirsa, Epistemologické problémy poznání sebe sama, str. 93-105; obdobně A. Joose, Dialectic and Who We Are in the Alcibiades, str. 12.

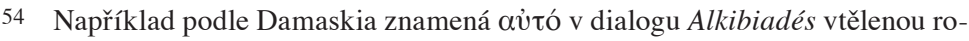

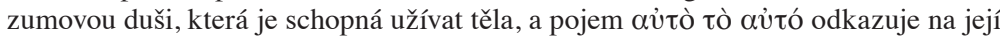
očištěnou a kontemplující podobu, která je nevtělená a bytostně spojená s pravdou. Proklos rozlišuje ,já““ ( $\alpha u ̛$ tó), což je duše v politickém životě, vtělená a trojdílná,jak

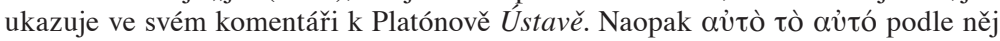
odkazuje k rozumové části duše (viz Proklos, In Platonis rem publicam I,172,4-6). Podle Olympiodora je pravým já obecná, rozumová duše (srv. Olympiodoros, In Plat. Alc. 202,2-5). Pro obecný přehled antických interpretací viz C. Gill, Self-Knowledge In Plato's Alcibiades, str. 98-99; podrobněji viz F. Renaud - H. Tarrant, The Platonic Alcibiades I: The Dialogue and its Ancient Reception, kap. 3; A. P. Segons, Proclus: Sur le premier Alcibiade de Platon, str. vii-civ.

55 R. Allen, Note on Alcibiades I, 129B 1, in: The American Journal of Philo-

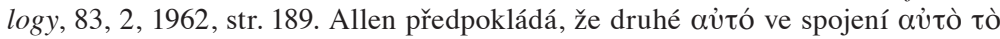

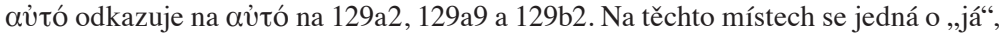
kterým je zřejmě duše. Proto Allen předpokládá, že jde o ,já samo“. 


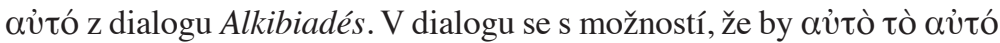
odkazovalo k ideji, nijak nepracuje. Dokonce i další autoři, podle nichž

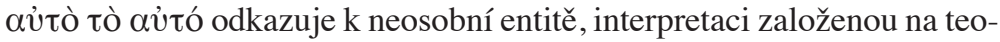
rii idejí odmítají. ${ }^{56}$ Např́klad podle Davida Johnsona tímto neosobním

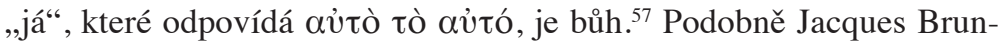

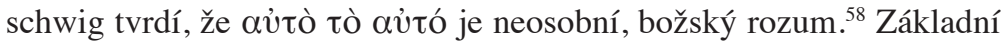
problém neosobní interpretace však spočívá v tom, že dané zkoumání má Alkibiada nejen přivést k lepšímu poznání sebe sama, ale také zaručit, že Alkibiadés nebude omylem pečovat o něco jiného, než o sebe sama. Je-

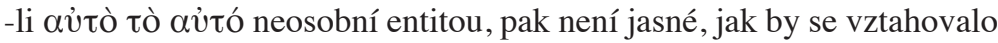
$\mathrm{k}$ tomuto praktickému ohledu péče o sebe, který je explicitním tématem dialogu..$^{59}$

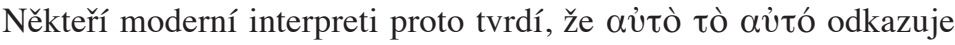
k vlastnímu ,já“, které není neosobní. Jean-François Pradeau se domnívá, že tématem dialogu je ,jác“ (soi) nebo „subjekt“" ve smyslu osoby (sujet) a že pasáž 129d-130d se snaží vysvětlit přechod od zájmena (soi) k podstatnému jménu (le soi), k čemuž používá podivné spojení aủiò

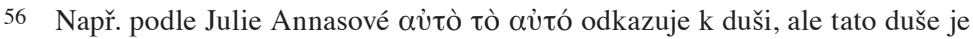
neosobní a stejná ve všech svých instanciacích (což jsou partikulární ,jáa“, aủiò

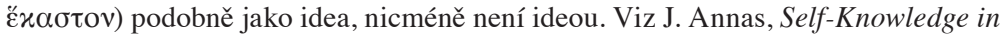
Early Plato, str. 131; podobně s Allenovou tezí nesouhlasí D. M. Johnson, God as the True Self, str. 7.

57 D. M. Johnson, God as the True Self, str. 10-11. Jeho výklad se opírá o pasáž

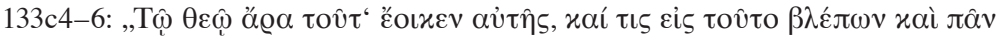

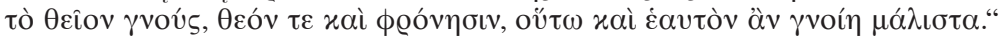

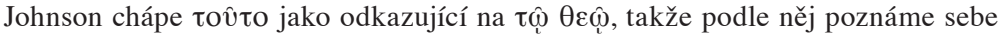

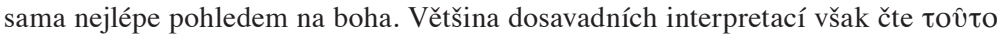

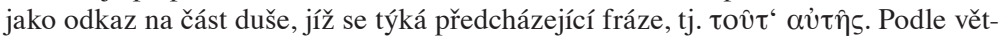
šinové interpretace poznáme sama sebe nejlépe pohledem do té části duše (či na tu část duše), která je bohu podobná. Johnson pro své čtení argumentuje tím, že pojem boha je zdůrazněn postavením $\tau \hat{u}$ $\theta \varepsilon \hat{u}$ na začátek věty a opakováním, že pohledem na božské poznáme boha $(\theta \varepsilon o ́ v)$. Přikládáním se $\mathrm{k}$ většině interpretů, že toto čtení

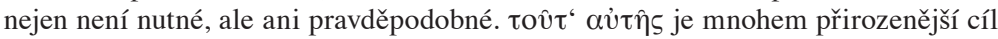

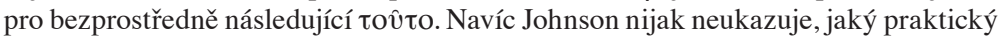
dopad by tato theologická interpretace měla, případně jak by byla zohledněna v pasážích dialogu Alkibiadés, které ukazují dopady poznání sebe sama na praktický život (133d a násl., srv. moji interpretaci níže).

58 J. Brunschwig, La déconstruction du „connais-toi toi-même“ dans l'Alcibiade Majeur, str. 70-71 a 76-77.

59 Další důvody proti neosobní interpretaci shrnuje A. Joosse, Dialectic and Who We Are in the Alcibiades, str. 11-12. 


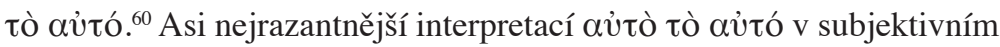
smyslu je výklad Michela Foucaulta $v$ jeho přednáškách na Collège de

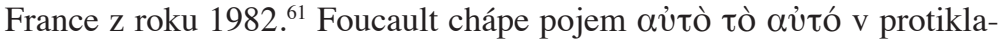
du ke karteziánskému pojetí ,jaa“", které podle něj zakládá moderní ,já“

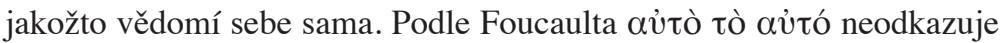
k dalšímu zkoumání, čím bytostně či v nějakém významném slova smyslu jsme, neodkazuje na entitu či substanci skrytou v základech našeho já. Platón podle něj otevírá otázku subjektu: sousloví aủtò tò aủ tó na 129b1 má ukazovat vztah, kdy je každá z jeho částí vždy zároveň subjektem a objektem. ${ }^{62,63}$

Všechny tyto rozdílné interpretace mají dvě věci společné. A právě tyto dva aspekty mi stačí, abych mohl pokračovat ve své tezi o různých typech ,já“ představovaných v dialogu Alkibiadés. Zaprvé, spojení

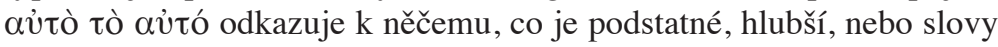

60 J.-F. Pradeau, Introduction, in: C. Marboeuf - J.-F. Pradeau, Platon, Alcibiade, Paris 1999, str. 47-53.

61 M. Foucault, L’herméneutique du sujet: Cours au Collège de France (1981-1982), Paris 2001. Používám anglický překlad in: M. Foucault, The Hermeneutics of the Subject: Lectures at the Collège de France 1981-82, přek1. G. Burchell, New York 2005.

62 M. Foucault, The Hermeneutics of the Subject, str. 53. Foucaultova interpretace si všímá mnoha zajímavých aspektů a je skvělým filosofickým výkonem. Tyto zajímavé momenty však interpretuje svébytným zpo̊sobem, který jde za hranice dialogu Alkibiadés, a ve svém zdůraznění individuality a subjektivity zřejmě také za hranice antického myšlení obecně. Pro kritické zhodnocení Foucaultovy interpretace viz A. Joosse, Foucault's Subject and Plato's Mind: A Dialectical Model of Self-Constitution in the Alcibiades, in: Philosophy and Social Criticism 41, 2, 2015, str. 159-177.

63 Oproti těmto interpretacím, které předpokládají, že $\alpha u ̛$ tó znamená cosi jako osobní či neosobní „sám“ ve smyslu ,já sám“, připomíná Nicholas Denyer, že aủ ó nemusí mít jakýkoli užší smysl „,sám“ ve smyslu osoby či mysli (angličtina zde obdobně zápasí s překladem „,self“). Jeho příkladem je věta „samu Oresteiu mám rád,

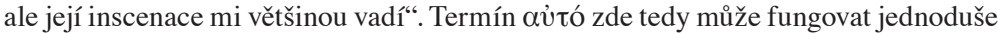
jako princip individuace (viz N. Denyer, Plato: Alcibiades, str. 211-212). Denyerův

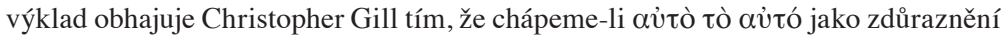

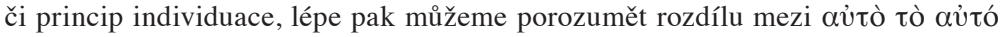

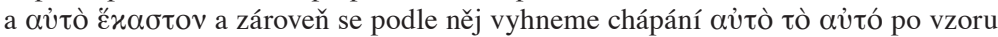
moderního ,já“ založeného na vědomí a vztahu vědomí k sobě samému (viz C. Gill, Self-Knowledge In Plato’s Alcibiades, str. 102-103). Výhoda lepšího chápání pro-

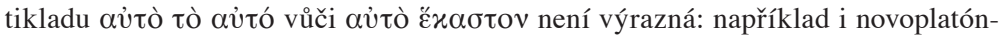
ská distinkce dává v antickém kontextu dobrý smysl; v moderních interpretacích

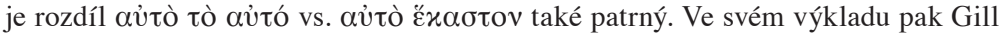
zcela opomíjí dialog Charmidés, kde se ukazuje, že Platón se věnuje či alespoň blíží problematice sebe-reflexivního vztahu vědění v kontextu poznání sebe. Viz pozn. 35. 
Christophera Gilla, co je jádrem něčeho více zjevného a nám, konkrét-

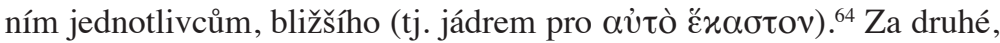

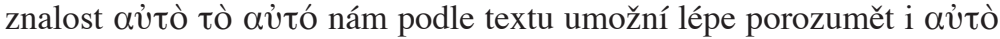

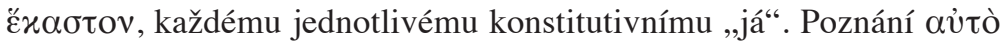

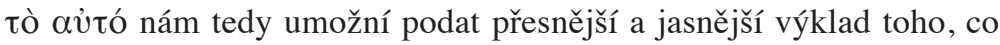
znamená, že , já““ je naše duše. ${ }^{65}$

Jak jsem již řekl, dialog Alkibiadés se explicitnímu výkladu o aủiò

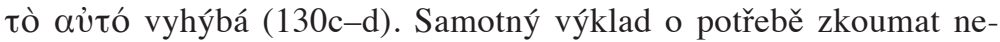

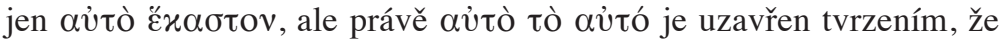
,jistě bychom nepokládali žádnou složku nás samých za významnější

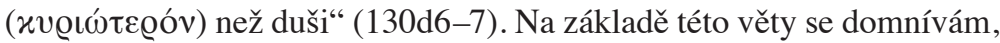

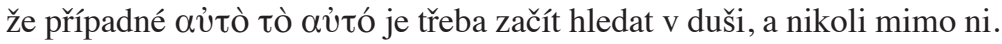
Po identifikaci člověka a duše se Sókratés opět dostává k otázce poznání sebe sama (130e7-8), které je chápáno zároveň jako péče o sebe samé (132b4-5, c1-2). K duši se pak Sókratés vrací i v popisu vlastního poznání sebe sama (133b7-c6):

„Sókr.: Jistě tedy, milý Alkibiade, také duše, má-li poznat samu sebe,

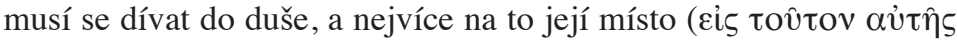

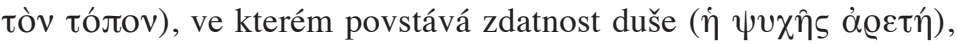
moudrost, a na další, co je tomu podobné. ${ }^{66}$

Alk.: Mně se zdá, že ano, Sókrate.

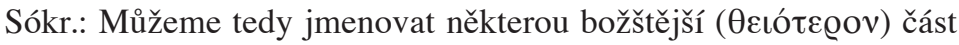
duše nežli tu, které náleží vědění a myšlení?

Alk.: Nemůžeme.

Sókr.: Tedy tato její část se podobá bohu, a kdo se do ní dívá a pozná

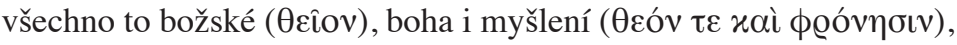
poznal by takto nejlépe i sám sebe.“67

64 C. Gill, Self-Knowledge In Plato's Alcibiades, str. 102.

65 Koncept duše není vlastním tématem dialogu Alkibiadés a nenajdeme v něm ani delší pasáže popisující duši jako třeba v dialogu Faidros, Faidón a samozřejmě v Ústavě a Zákonech. Kromě toho, že v jistém slova smyslu jsme duší, se o duši z dialogu dozvíme, že užívá tělo a vládne mu (130a1, 130a12), že je tím nejvýznamnějším v nás (130d6-7), že užívá řečí (130d9-11), že má různá místa, resp. části a že její ctností je moudrost (133b7-c6).

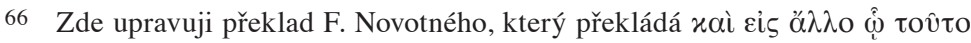

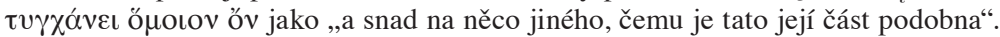
Uvedený překlad až příliš naznačuje existenci jedné entity mimo duši, která je podobná tomuto místu v duši.

$67 \mathrm{~K}$ poslední větě citovaného textu viz pozn. 57. 
Sám sebe tedy nejlépe poznám pohledem do té nejvíce božské části duše. Domnívám se, že tímto místem či touto částí duše je rozum, a to ačkoli

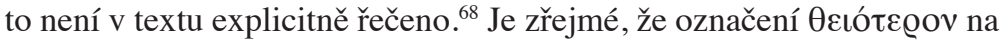

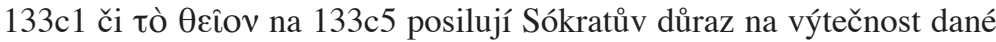

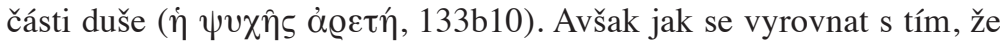
poznání této oblasti nás přivede i k poznání boha (133c5)? ${ }^{69}$ Rozhodně není možné, abychom v prvním kroku poznali sebe sama pohledem mimo duši, Sókratés stále hovoří o poznání duše, respektive daného místa $\mathrm{v}$ duši (133b8-9, 133c4-5). ${ }^{70}$

Analogickou pasáž, která nám zde může pomoci při interpretaci, lze nalézt v dialogu Faidros, 252e-253a. Podle Sókratova výkladu v Palinodii žije člověk, tj. vtělená duše, při prvním zrození na tomto světě ,podle toho boha, jehož doprovázel“ (252d2-3). Ti, jejichž duše doprovázely Dia ${ }^{71}$ zkoumají, zda je jejich miláček ,nadaný pro filosofii a vůdcovství“ (253e2). Když někoho takového naleznou, tak se oba oddávají učení, zkoumání a hledání, aby našli „sami u sebe přirozenou povahu svého boha“ (252e5-253a1). To se jim zdaří díky silnému nutkání či nucení

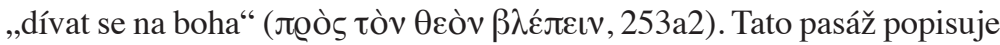
milostný vztah těch, jejichž bohem je Zeus. Jejich snahou je nalézt přirozenou povahu boha v nich samých ( $\left.\pi \alpha \varrho^{`} \dot{\varepsilon} \alpha v \tau \hat{\omega} v, 253 \mathrm{a} 1\right)$, přičemž jsou vedeni nutností dívat se na boha, stejně tak jako se má duše v dialogu

68 K podobnému závěru dochází P. Remes, Reason to Care: The Object and Structure of Self-Knowledge in the Alcibiades I., str. 296; ohledně pohledu duše srv. Resp. 433d2, kde se je rozum nazván okem duše.

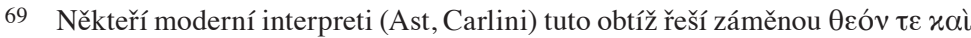

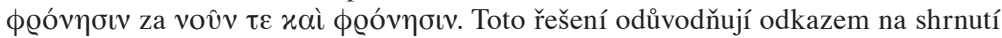

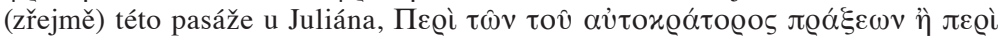
$\beta \alpha \sigma \iota \lambda$ eías, 15,13-14 = 68D. Srv. A. Carlini, Alcibiade, Alcibiade Secondo, Ipparco, Rivali, Torino 1964, str. 239. U Juliána je patrná snaha chápat danou pasáž ryze psy-

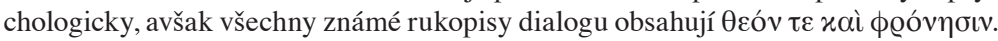

70 Například Albert Joose ukazuje, že k poznání boha samého může vést dialektická cesta od poznání božské části duše; viz A. Joose, Dialectic and Who We Are in the Alcibiades, str. 17-18. Podobně Pauliina Remes chápe zmínky o božství především jako zdůraznění normativního aspektu poznání sebe sama, nikoli jako poznání božské bytosti či entity mimo lidskou duši; viz P. Remes, Reason to Care: The Object and Structure of Self-Knowledge in the Alcibiades I., str. 294. Ke spojení rozumu a boha v Platónově filosofii srv. S. Menn, Plato on god as nous, Carbondale 1995. Můj výklad podporuje i interpretace v F. Renaud - H. Tarrant, The Platonic Alcibiades I: The Dialogue and its Ancient Reception, str. 68-69.

71 Sókratés zde hovoří tak, že je jasné, že pokládá duši za naše já: identifikuje nás zde v tomto pozemském bytí s dušemi, které provázely bohy na jejich nebeské cestě (Phaedr. 247b). 
Alkibiadés při poznání sebe samé dívat do té části duše, kde pozná boha. ${ }^{72}$ I v dialogu Faidros se tedy hledí na boha, jehož přirozenost se nachází v našem nitru. Gerson Rabinowitz na tomto místě identifikuje pohled duše do místa v duši, kde se nachází bůh či rozum (nús), s platónským pojetím filosofie jakožto poznání i očišt'ování duše zároveň, což naprosto odpovídá i dialogu Alkibiadés. ${ }^{73}$

Popisovaný krok v rámci procesu poznání sebe sama je tedy poznání rozumové části duše či místa duše, kde nalézáme rozum. Rozum má samozřejmě neosobní konotace, avšak v dialogu Alkibiadés se hovoří o poznání místa $\mathrm{v}$ duši druhého člověka. Téma celé rozpravy je bytostně praktické, Sókratovi s Alkibiadem jde o péči o Alkibiada, a nikde není ani naznačeno, jak by mohl být proveden přechod od neosobního ,já“ k péči o naše ,já“.

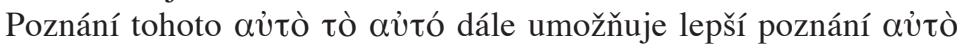

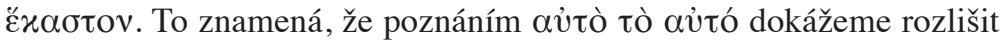
ohledy, v nichž je pravda, že jsme duší, i když ve vlastním slova smyslu jsme ponejvíce rozumem. Předpoklad částí či míst duše také umožňuje vyložit variabilitu lidských duší, jak jsme výše viděli v pasážích z dialogu Faidros. Avšak i tuto odpověd dialog pouze naznačuje a nikde v něm nenajdeme detailnější výklad o nejbožštější části duše. Svůj výklad o rozdílných identitách či odpovědích na otázku „Kdo jsem?“ tedy formuluji za předpokladu, že první, nepřesná, ale prakticky postačují-

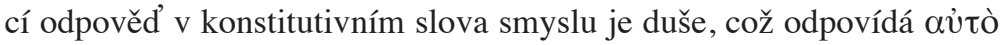

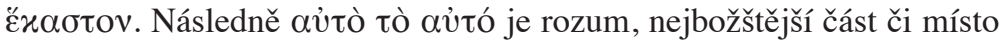
duše, tato přesnější odpověd’ však není v dialogu rozpracována.

V tomto ohledu tedy druhá část dialogu Alkibiadés pojednává o tzv. konstitutivním ,já“. Toto ,já“ je zde chápáno jako duše, což však není úplný a přesný výklad, který by byl možný teprve na základě znalosti

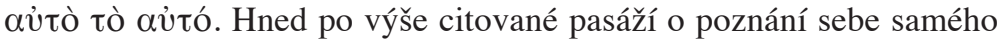
se Sókratés s Alkibiadem vrátí k praktickým důsledkům poznání sebe sama pro náš život v obci. Tím se vrací na scénu dialogu téma praktické identity. V následující, závěrečné části bych se proto rád věnoval vzájemnému vztahu různých významů ,jác“, který je načrtnut v závěrečných pasážích dialogu.

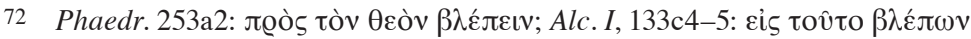

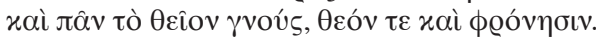

73 G. Rabinowitz, Aristotle's Protrepticus and the Sources of its Reconstruction, Berkeley - Los Angeles 1957, str. 64; Rabinowitz dále odkazuje na dialog PhD. 67c. 


\section{Praktická identita a konstitutivní ,já“}

Výše jsem předvedl, jak se v dialogu Alkibiadés objevují dva typy „jä“, resp. dvě navzájem nepřevoditelné možnosti, jak odpovědět na otázku „Kdo jsem?“. První část dialogu Alkibiadés probírá Alkibiadovu praktickou identitu a jeho integritu $v$ rolích, $v$ nichž sám sebe chápe a ve kterých skutečně funguje. Sókratés odhaluje vady a trhliny v Alkibiadových chybných představách o sobě samém a s využitím studu dostane Alkibiada k možné nápravě: péči o sebe samého. Druhá část dialogu se pak soustředí na entitu, které se má dostat této péče, tj. na otázku po konstitutivním ,jä“. Tyto dva významy nejsou stejné, není totiž možné nahradit diskusi o praktické identitě rozborem lidské duše a vice versa. Diskuse o praktické identitě je založena na ambicích a záměrech Alkibiada, který je z masa a kostí, který žije $\mathrm{v}$ daném městě a $\mathrm{v}$ dané společnosti. Alkibiadova dianoémata o sobě samém jsou založená na jeho krásné, vysoké postavě, na jeho původu a bohatství. Jeho názory jsou utvářené obcí a společností, která jej obdivuje.

Druhá část dialogu - diskuse o duši jakožto našem konstitutivním ,jáa“ - pak dovedla Sókrata a Alkibiada k základům našeho ,já“. Výklad začal od vnějších nástrojů, jichž užíváme, a skrze úvahy o lidském těle se dostal až ke skrytému ,jáa“, které je ,já“ ještě v hlubším slova smyslu než naše duše. Tento výklad také obsahuje náznaky úvah o našem vztahu $\mathrm{k}$ bohu či božství a o postavení duše v širším metafyzickém kontextu kosmu. ${ }^{74}$ Výklad o poznání sebe samého tak postupně prochází celým dialogem a směřuje víc a víc do hloubky: od praktické identity vede ke

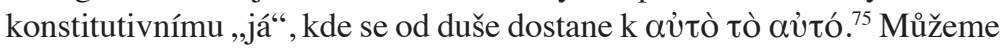
si představit uspořádání různých typů ,jä“ v podobě soustředných kruhů: skutečnost, že jsme lidskými bytostmi, je důležitým základem pro praktické identity, které žijeme v našich vtělených životech ve společnosti. Otázka „Co je člověk?“ následně vede Sókrata k částečnému výkladu o konstitutivním ,já“ (o částečném výkladu hovořím proto, že dialog

$74 \mathrm{~K}$ theologickému rámci této diskuse srv. D. M. Johnson, God as the True Self: Plato's Alcibiades I., a P. Remes, Reason to Care: The Object and Structure of Self-Knowledge in the Alcibiades I., str. 287-296.

75 Tento postup v rámci diskuse o konstitutivním ,já“ je navržen Brunschwigem (J. Brunschwig, La déconstruction du „connais-toi toi-même“ dans l'Alcibiade Majeur, str. 77), a následně je převzat v článcích: D. M. Johnson, God as the True Self: Plato's Alcibiades I., str. 2, a C. Gill, Self-Knowledge In Plato's Alcibiades, str. 106-107. 


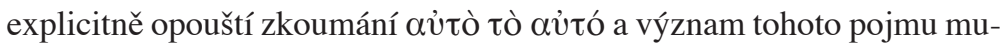
síme určit z jistých náznaků v rámci pasáže o poznání sebe sama, $\mathrm{k}$ tomu viz výše).

Dialog Alkibiadés však nekončí tímto ponorem ke konstitutivnímu „já“. Na řádku 133c21 Sókratés diskusi uzavírá odkazem na vztah mezi tímto ,já “ a bohem či božstvím: pohledem na božské, boha a rozumnost, bychom zároveň poznali i sami sebe. Tím bychom splnili podmínku, podle níž pro náležitou péči o sebe sama musíme znát samotný předmět naší péče, tj. nás samé (133c21-23, 133d5-6). Podle Sókrata není možné napravit chyby a mylné představy o nás samých, aniž bychom poznali, co jsme ve smyslu konstitutivního ,já“. Jen tento epistemologický výkon zaručí, že naše jednání bude správné a dobré (134d10), a tak budeme žít št'astně (134e2).

Tato pasáž jasně ukazuje, že nelze zaměňovat praktickou identitu (vzhled, původ, majetek a vzdělánî) s tím, čím jsme ve smyslu duše, či dokonce rozumu. Podle textu dialogu sice jedno poznání vede k poznání nás samých, toho, co je nám vlastní, i těch věcí, které přináleží $\mathrm{k}$ tomu, co je nám vlastní (133e1). Nelze však zaměňovat ,jáa“ například s tím, co danému , já “ náleží. K tomu Sókratés přidává, že takové stejné poznání je klíčové pro poznání toho, co je vlastní jiným lidem (133e4-5). Proto se ukazuje, že právě toto poznání je klíčové i pro správu obce, pro skutečné politické povolání, $\mathrm{k}$ němuž se zprvu Alkibiadés pokládal za předurčeného díky svým výhodám a přirozeným talentům (104a3). Ty se však nyní ukazují jako velmi vzdálené předmětu poznání, které je pro politiku klíčové.

Text dialogu Alkibiadés se zde vrací z metafyzické a theologické úrovně zkoumání poznání sebe sama a jeho předpokladů až na úroveň praktického života. Tématem dialogu již není bezprostředně naše konsti-

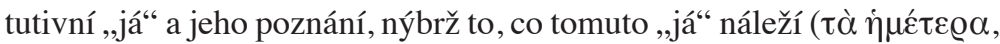
133d5). Sókratovu argumentaci lze rozvést v podobném duchu, jaký nacházíme při výkladu o prospěšnosti rozumu a vědění v dialogu Menón, 87e-89a, kde se také správné užívání ukazuje jako podmínka prospěšnosti věcí, které lze $\mathrm{k}$ něčemu užívat, jako je zdraví, krása, moc či bohatství (87e5-88a5). Pokud neznáme samy sebe, říká Sókratés v Alkibiado$v i$, nemůžeme znát ani svoje věci - jsou-li vůbec naše. Jak máme vědět, co k nám patří, co je pro nás důležité, když nevíme, kdo či co jsme? Neznalí lidé chybují. Neznalost je prř́činou omylů, chyb a špatného jed-

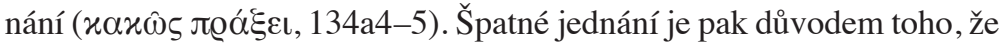
lidé nejsou ve svých životech št'astní. Naopak št’astní jsou ti, kteří jsou rozumní a dobří, tj. jednají rozumně a dobře (134a13-14). 
Výše uvedené úvahy se podle Sókrata týkají jak soukromých, tak ve-

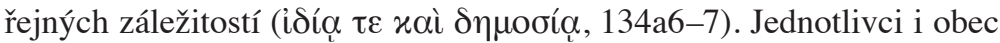
potřebují k tomu, aby prospívali a byli št’astní ( $\varepsilon \dot{v} \delta \alpha u \mu o v \varepsilon ́(\omega)$, nejen

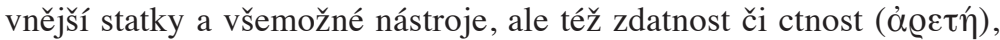
která jim zaručí dobré jednání a nechybování (134b7-9). Zde se tedy dialog vrací o několik stran zpět k otázce, „Co musí být přítomno nebo co musí být vzdáleno, aby byla obec lépe spravována a bez pohromy?" (126a5-6). Sókratés následně uvádí příklad: kdyby se jej někdo zeptal, co musí být přítomno, aby byly v dobrém stavu oči, odpověděl by, že zrak, a neprrítomná musí zůstat slepota. Je-li tedy odpovědí, že obec je dobře spravována a bez pohromy, když je přítomna ctnost, je zřejmé, že tato pasáž předpokládá obdobný vztah mezi danou entitou, její činností

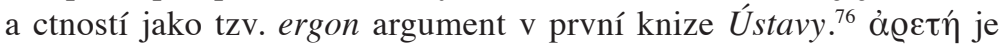
vlastnost, která umožňuje dané entitě dobré a náležité naplnění jejího

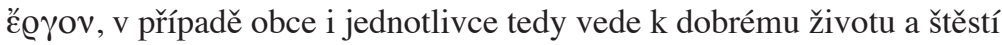

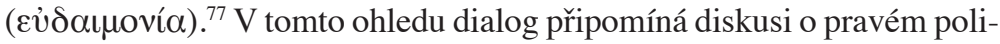
tickém umění v dialogu Gorgias, které se nezajímá jen o doky či hradby, ale jehož skutečným předmětem jsou ctnosti (521d6-8).

Proč je tedy poznání konstitutivního ,jác“ důležité pro jednání v rámci našich praktických identit? Nelze poznat, a tedy ani provozovat umění péče o sebe bez znalosti sebe sama (128e11-12). K čemu však je péče o konstitutivní , já “? Před vyjasněním otázky po péči je třeba připomenout samotný přínos poznání sebe samého. Bez znalosti sebe sama nelze znát ani své věci, nakolik jsou dobré a zlé (133c21-23). Bez znalosti sebe sama tedy neznáme hodnotu věcí, které k našemu konstitutivnímu „já“ náležejí. Tato znalost však není omezena jen na naše či mé věci. Tato znalost má společenský rozměr: bez znalosti sebe samého neznáme ani druhé a jejich věci (133d1-3). Tento společenský či mezilidský rozměr je podle mne výsledkem procesu poznání sebe samého jakožto střetnutí $d v o u$ duší, které bylo popsáno výše. K tomuto vzájemnému vztahu dvou duší náleží také to, že poznávající hledí na zdatnost duše, na její ctnost. Poznání této dokonalosti pak může být klíčem pro porozumění nejen mne samému, ale i ostatním: ${ }^{78}$ jedním uměním, jednou znalostí

76 Platón, Resp. 352d-353c.

77 Můžeme zde tedy rozeznat dva pohledy na to, jak ỏ @etń přispívá k dobrému životu: (a) ỏ@etí je zde odvozena od vědění a jako taková zaručuje, že nebudeme chybovat, nýbrž jednat správně; (b) zároveň je ỏ@etí vlastnost, skrze niž uskutečňujeme naše vlastní ع̣̌jov, a v jistém slova smyslu tedy naplňujeme to, co máme být.

78 Podobně argumentuje F. Renaud - H. Tarrant, The Platonic Alcibiades I: The Dialogue and its Ancient Reception, str. 77-78. „Mé věci“ a „věci druhých“ lidí 
poznáváme sebe samého, své věci a věci těchto věcí, zároveň také věci jiných lidí (133d12-e5). ${ }^{79}$ Jelikož znalost sebe samého je tedy v tomto slova smyslu komplexní, je lépe pochopitelné, že jejím důsledkem je nechybování v našem životě.

Dále je poznání sebe samého předpokladem péče o sebe, ve které se danému ,„já“ dostává náležité zdatnosti či ctnosti (viz výše moji argumentaci ohledně schématu ergon argumentu v dialogu Alkibiadés). Bylo řečeno, že v politickém boji Alkibiadés nemůže spoléhat na nic

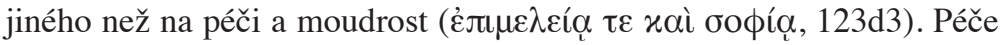
se mu dostává díky poznání sebe samého ${ }^{80}$ a moudrost je ctností, kterou poznává během poznání sebe samého (133b9-10). Když se tedy Alkibiadés v první části rozhodne, že by o sebe měl pečovat, Sókratés následně zkoumá, jak se stát co nejlepším (124b10-c2). Jak jsme viděli výše, dobrým, resp. nejlepším se každá entita stane „přistoupením“ relevantní ctnosti (126b2-7, 134c5-8), v našem př́padě tedy díky ctnosti, kterou nabydeme poznáním sebe samých. ${ }^{81}$ Jen tímto způsobem se tedy Alkibiadés může stát skutečným protivníkem velkých králů. Alkibiadés nemůže být perským či lakedaimonským panovníkům roven bohatstvím či vzděláním, může však být nositelem ctnosti, která jej činí lepším (a méně chybujícím) než jsou oni. Poznání sebe samého tedy s sebou přináší

odkazují k tělu, penězům a obecně majetku (srv. explicitně $131 b-c)$; znalost těchto věcí tedy Platón podmiňuje znalostí konstitutivního ,já““. Tato znalost je také klíčová pro správné jednání ve veřejném i soukromém životě (134a), takže je také základem pro správné chápání naší praktické identity. K obecnému či individuálnímu charakteru konstitutivního ,já““ viz výše pozn. 56 a 57, srv. též 60.

79 N. Denyer upozorňuje na možný rozpor s dialogem Filébos, 48c-e, kde Sókratés tvrdí, že lidé, kteří neznají sebe sama, projevují svoji neznalost v přeceňování svého majetku, tělesné krásy a ctnosti duše (N. Denyer, Plato: Alcibiades, str. 239). Tato pasáž podle Denyera předpokládá, že dotyční vědí o svém majetku, těle a duši, i když neznají sebe sama. Rozpor je však zdánlivý: podle dialogu Filébos se dotyční

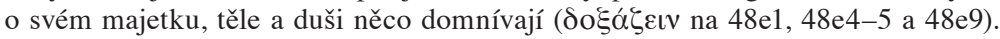
To není nutné chápat tak, že mají v této věci skutečné poznání či pravdivé mínění. Stejně tak nyní Sókratés reaguje na předchozí pasáž 131a2-b2, kde hovořil o tom, že lékaři a ostatní řemeslníci mohou znát to, co nám náleží, ale neznají sebe samé: tato úvaha byla mylná, jelikož kdo nezná sebe, nemůže znát, co mu náleží (133d10-e1; srv. Meno, 71b).

$80 \mathrm{~K}$ autoritě a praktickým aspektům poznání sebe samého srv. J. Jirsa, Epistemologické problémy poznání sebe sama, str. 93-105.

81 Poznání sebe samého je rozumnost (ф@óvๆoıs, 133c18-19); během poznání sebe samého poznávající hledí na moudrost, avšak samotné poznání sebe samého je v kontextu praktického užití tohoto poznání soustavně označováno za rozumnost $(133 \mathrm{c} 23,134 \mathrm{a} 13, \mathrm{~b} 5)$, respektive rozumnost a spravedlnost (134d1). 
korektivy a normativní standardy jednání v soukromé i společenské ob-

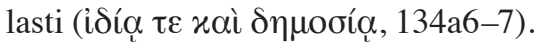

Domnívám se proto, že výše předvedený postup od jednoho typu ,já““ $\mathrm{k}$ dalšímu je zároveň postupem $\mathrm{v}$ důležitosti. Tím však rozhodně nechci říci, že by nezáleželo na tom, zda je Ión dobrý rapsód nebo Alkibiadés dobrý politik. Závěr dialogu Alkibiadés naopak ukazuje, že znalost konstitutivního ,já“ je nezbytnou podmínkou, abychom v našich praktických identitách uspěli, abychom dobře jednali a byli št’astní. V poslední větě dialogu Sókratés zmiňuje obec jako sílu, která může přemoci Alkibiada i jeho (obojí se také - u každého v jiném slova smyslu - stalo). Smyslem této lakonické poznámky na závěr je čtenáře upozornit, že standardy našeho jednání, toho, co je správné či špatné, musí být získány znalostí

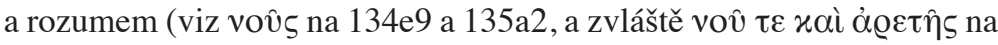
135a6-7). Tyto standardy nemají být odvozeny od toho, co si myslí obec, prrípadně co si myslí či mysleli Alkibiadovi bývalí milovníci.

Zde se tedy ukazuje důležitý vztah mezi jednotlivými typy „jáa, o nichž pojednává dialog Alkibiadés. Předpokládáme-li koncentrický obraz jednotlivých ,jáa, pak vnitřní ,já“ vždy poskytuje normativní základ pro správné fungování vnějšího ,jáa“. V rámci dialogu Alkibiadés je

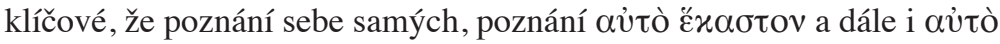

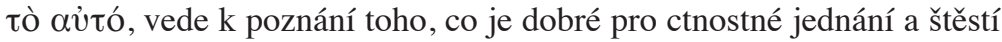
nejen nás samých či naší nejvyšší části, ale i pro celou obec. Poznání konstitutivního ,já““ tedy zakládá naše správné fungování jakožto lidské bytosti, včetně naší praktické identity, která zahrnuje i správu věcí veřejných, tj. politiku.

\section{Závěr: Sókratův odkaz}

Výše jsem předvedl, jak se první polovina dialogu Alkibiadés věnuje naší praktické identitě. Druhá polovina zkoumá konstitutivní ,já““. V závěru dialogu pak Sókratés načrtává jistý normativní vztah mezi tím, čemu říkám praktická identita, a konstitutivním ,jác“. Poznání tohoto „hlubšího já" se ukazuje jako klíčové pro správné provozování našich praktických identit, a tedy pro náš dobrý život, včetně politického povolání.

Téma dialogu je tedy tématem jak etickým, tak politickým. ${ }^{82}$ Sókratés je zde představen nejen jakožto pravý politik, který pečuje o ctnosti

82 Viz F. Renaud - H. Tarrant, The Platonic Alcibiades I: The Dialogue and its Ancient Reception, str. 230-231. 
občanů (ve smyslu pravé politiky zmíněné výše v souvislosti s dialogem Gorgias), ale v samém závěru také jako pravý pedagog, který by mohl být schopen změnit kurz Alkibiadovy politické kariéry (135d-e). V tomto ohledu dialog Alkibiadés nejen rozpracovává téma péče o sebe tím, že rozebírá různá pojetí , já“", ale zároveň může sloužit jako možná obhajoba Sókrata proti nařčení, že kazí mládež (Obrana 24b-c). V samém závěru totiž Alkibiadés slibuje, že bude pečovat o spravedlnost (135e4-5), a i kdyby čtenář $\mathrm{k}$ jeho tvrzení přistupoval s oprávněnou nedůvěrou, Sókratés odpovídá:

„Chtěl bych, abys v tom také setrval; ale mám obavy - ne že bych

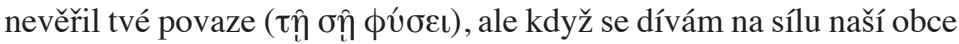
(

Alkibiadova povaha, o jejíž pravé podobě se právě dozvěděl, je zde stavěna do protikladu k síle obce. Zároveň tak jako Alkibiadés o chvilku dřive spojuje svůj osud se Sókratem (135d7-11), tak zde Sókratés spojuje svůj osud s Alkibiadem v obavě, že oba budou přemoženi silou obce. O Sókratově osudu víme z Obrany a z jiných zdrojů. Konec dialogu naznačuje, že Sókratés svádí ohledně Alkibiada zápas s obcí. Sókratés jej chce přivést k poznání sebe sama, a tím pádem zajistit náležitou péči o sebe samého. Naopak obec, která zřejmě zůstává u oceňování Alkibiadovy postavy, původu a bohatství, takovému pravému poznání sebe samého brání. I závěr dialogu by tedy mohl být čten tak, že poukazuje na nutnost poznání sebe sama v jiném slova smyslu, než jaké ,jaa“ a s ním spojené hodnoty uznává sama obec. ${ }^{84}$

\section{ZUSAMMENFASSUNG}

Im Artikel werden zwei mögliche Antworten auf die Frage „wer bin ich?" unterschieden, die im Dialog Alkibiades I gestellt wird. Die erste Antwort wird mit Hilfe von Begriffen unserer praktischen Identität gegeben, die im ersten Teil des Dialogs zur Sprache kommt. Die zweite Antwort betrifft unser tieferes, grundlegendes Selbst, dessen Problematik im

83 Platón, Alc. I, 135e6-8.

84 Tato práce vznikla za podpory projektu Kreativita a adaptabilita jako předpoklad úspěchu Evropy v propojeném světě reg.č.: CZ.02.1.01/0.0/0.0/16_019/0000734 financovaného z Evropského fondu pro regionální rozvoj. 
zweiten Teil des Dialogs behandelt wird. Obwohl andere Interpretationen von verschiedenen Arten von „Selbst“ im zweiten Teil des Dialogs ausgehen, zeigt meine Interpretation, dass die verschiedenen Begriffe von „Selbst“ quer durch den ganzen Dialog zu finden sind. Schließlich erörte ich die Beziehung zwischen den verschiedenen Entwürfen von Selbst, um zu zeigen, in welchem Sinne das wesentliche „Selbst“ als ein normativer Grund für unsere praktische Identität dient.

SUMMARY

The article distinguishes two possible answers presented by the Alcibiades I regarding the question "Who am I?". The first answer is carried out in terms of our practical identity, as it is discussed in the first part of the dialogue; the second answer concerns our deeper, constitutive self, uncovered in the second part of the dialogue. Whereas other interpretations look for different senses of the "self" in the second part of the dialogue, my interpretation shows that distinct concepts of the "self" are to be found across the entire dialogue. In conclusion I address the relation between these two concepts of the self in order to show in what sense the constitutive "self" serves as a normative ground for our practical identity. 